\title{
The environmental impact of rearing crickets for live pet food in the UK, and implications of a transition to a hybrid business model combining production for live pet food with production for human consumption
}

\author{
J. Suckling ${ }^{1}$ (D) A. Druckman ${ }^{1} \cdot$ C. D. Moore ${ }^{2} \cdot$ D. Driscoll ${ }^{3}$
}

Received: 30 March 2020 / Accepted: 31 May 2020 / Published online: 1 July 2020

(C) The Author(s) 2020

\begin{abstract}
Purpose Rearing crickets in the UK for the live pet food market is already a well-established industry. However, there is interest in also producing food for human consumption. This paper presents a life cycle assessment (LCA) of a current live pet food business. Using results from this LCA, the papers explores how current business practices could be improved to reduce environmental impacts, and discusses the potential benefits of a hybrid live pet food/human consumption business model.

Methods An attributional, cradle-to-farm-gate life cycle assessment was conducted on rearing crickets for the live pet food market, with data collected on-site at a case study business. Results are reported in multiple impact categories from the ILCD 2011 Midpoint+ method. Comparison is made to the only other similar study: an LCA of rearing crickets in Thailand for human consumption (Halloran et al. J Clean Prod 156:83-94, 2017). The sources of the different environmental impacts between the two studies are explored and inefficiencies in the live pet food rearing process identified. Subsequently, scenarios are used to explore how the inefficiencies may be mitigated, and environmental impact of the live pet food production process reduced through adoption of a hybrid live pet food/human food production model.

Results and discussions The environmental impact was found to be larger across all impact categories than the only known comparable study, which is for rearing crickets in Thailand for human consumption (Halloran et al. J Clean Prod 156:83-94, 2017). Some of this difference is due to the heating required for rearing crickets in a climate such as the UK, and some is due to the requirements of the live pet food market being much more demanding on resources than the human food model. The current study identifies improvements in practices that would make this contrast less stark, such as optimizing feeding practices, and the benefits of moving to a hybrid live pet food/human consumption business model.

Conclusions This is the first LCA of crickets reared in the UK. The results highlight inefficiencies in the rearing process that are now being addressed by the case study business. The study also shows the potential co-benefits of a hybrid business model, in which crickets for human consumption are produced alongside crickets for the live pet food market.
\end{abstract}

Keywords Life cycle assessment (LCA) $\cdot$ Crickets $\cdot$ Human food $\cdot$ Live pet food $\cdot$ Business model $\cdot$ Entomophagy $\cdot$ Insect farm

Electronic supplementary material The online version of this article (https://doi.org/10.1007/s11367-020-01778-w) contains supplementary material, which is available to authorized users.

A. Druckman

a.druckman@surrey.ac.uk

1 Centre for Environment and Sustainability, University of Surrey, Guildford, UK

2 School of Nutritional Sciences, University of Nottingham, Nottingham, UK

3 Department of Chemistry, University of Surrey, Guildford, UK

\section{Introduction}

Production and consumption associated with the human food supply chain is placing a significant strain upon the environment. In particular, much attention is given to the impacts caused by rearing livestock. Growing human populations and an increasing demand for meat in people's diets are now regarded as leading causes of global climate change, with $14 \%$ of all anthropogenic greenhouse gas (GHG) emissions attributed to rearing animals for human food (Gerber et al. 2013). This is compounded by the $38 \%$ of arable land which is used to grow crops to feed animals for human consumption (Foley 
et al. 2011). As a result, alternative sources of protein are an increasingly important area of research, and one particular avenue of interest is rearing insects as a source of both food for humans and feed for animals (van Huis et al. 2013; van Huis and Oonincx 2017). The attraction of insects is reduced GHG emissions (van Huis et al. 2013), land (Alexander et al. 2017) and water (Miglietta et al. 2015) requirements when compared to producing a similar quantity of protein from warm blooded animals. However, there are very few life cycle assessment (LCA) studies on rearing insects for use either as animal feed or for direct consumption by humans. A summary of existing LCAs is provided in Table 1. Of these studies, only Oonincx and de Boer (2012), Smetana et al. (2016, 2019a), Halloran et al. (2017), and Thevenot et al. (2018) use data from existing commercial rearing facilities.

This study fills an important gap in the literature, presenting the first LCA of cricket rearing in a country such as the UK. Indeed, the authors are only aware of one other LCA study on cricket rearing: this is by Halloran et al. (2017), who assessed the environmental impact of rearing of Gryllus bimaculatus (field crickets, also known as black crickets) and Acheta domesticus (house crickets) in Thailand for human food.

While use of insects in the supply chain of food for consumption by humans, either as feed to animals or for direct human consumption, is nascent within Europe, insects are used in the live pet food market, which is well-established. Live pet food refers to living, moving food (i.e., insects) fed to privately owned animals, such as lizards, which are not reared for human food. Common insects supplied to this market include various species of cricket (Gryllodes sigillatus, Gryllus assimilis, Gryllus bimaculatus, and Acheta domesticus), mealworms (Tenebrio molitor), and locusts (Schistocerca gregaria and Locusta migratoria). As there is a limited distance over which it is possible to ship a viable, living insect, the live pet food market is geographically localized, and hence, there are several relatively large established businesses in the UK supplying the domestic live pet food market.
Table 1 Summary of literature relating to life cycle assessment of rearing insects for food or feed. References include mealworms (Tenebrio molitor, or T. molitor), house fly larvae (Musco domestica, or M. domestica), black soldier fly larvae (Hermetia illucens, or H. illucens), black crickets (Gryllus bimaculatus, or G. bimaculatus), house crickets (Acheta domesticus, or A. domesticus), and earthworms (Lumbricus terrestris or L. terrestris)

\begin{tabular}{|c|c|c|c|}
\hline Species & Location & Study type & Author \\
\hline T. molitor & Netherlands & $\begin{array}{l}\text { Cradle-to-farm-gate LCA. T. molitor reared on carrots } \\
\text { and mixed grains. }\end{array}$ & $\begin{array}{l}\text { Oonincx and } \\
\text { de Boer } \\
(2012)\end{array}$ \\
\hline T. molitor & Netherlands & $\begin{array}{l}\text { Assessment of various meat alternatives. Extension of } \\
\text { prior LCA (Oonincx and de Boer 2012). }\end{array}$ & $\begin{array}{l}\text { Smetana et al. } \\
\quad(2015)\end{array}$ \\
\hline T. molitor & France & LCA of T. molitor reared on crops for animal feed. & $\begin{array}{l}\text { Thevenot } \\
\text { et al. (2018) }\end{array}$ \\
\hline T. molitor & France & $\begin{array}{l}\text { Attributional LCA of production of T .molitor for } \\
\text { incorporation into trout feed. }\end{array}$ & $\begin{array}{l}\text { Le Féon et al. } \\
\text { (2019) }\end{array}$ \\
\hline M. domestica & Netherlands & $\begin{array}{l}\text { LCA of M. domestica reared on poultry litter and food } \\
\text { waste. }\end{array}$ & $\begin{array}{l}\text { van Zanten } \\
\text { et al. }(2015)\end{array}$ \\
\hline M. domestica & Spain & LCA of M. domestica reared on pig manure. & $\begin{array}{l}\text { Roffeis et al. } \\
\text { (2015) }\end{array}$ \\
\hline H. illucens & Germany & $\begin{array}{l}\text { LCA of rearing } \mathrm{H} \text {. illucens on various feedstocks and } \\
\text { further processing for feed or food. }\end{array}$ & $\begin{array}{l}\text { Smetana et al. } \\
\quad(2016)\end{array}$ \\
\hline H. illucens & Italy & $\begin{array}{l}\text { LCA of H. illucens fed food waste for bioconversion into } \\
\text { feed or bio-diesel. }\end{array}$ & $\begin{array}{l}\text { Salomone } \\
\quad \text { et al. (2017) }\end{array}$ \\
\hline H. illucens & Netherlands & $\begin{array}{l}\text { LCA of } \mathrm{H} \text {. illucens fed food production side products for } \\
\text { producing feed and food. }\end{array}$ & $\begin{array}{l}\text { Smetana et al. } \\
\quad(2019 a)\end{array}$ \\
\hline H. illucens & Netherlands & $\begin{array}{l}\text { Attributional and consequential LCA of H. illucens for } \\
\text { feed and food. }\end{array}$ & $\begin{array}{l}\text { Smetana et al. } \\
\quad(2019 b)\end{array}$ \\
\hline H. illucens & Brazil & $\begin{array}{l}\text { Emergy assessment of } \mathrm{H} \text {. illucens reared upon grain } \\
\text { residues. }\end{array}$ & $\begin{array}{l}\text { Allegretti } \\
\text { et al. (2018) }\end{array}$ \\
\hline H. illucens & Italy & LCA of H. illucens reared on different substrates. & $\begin{array}{l}\text { Bava et al. } \\
\quad(2019)\end{array}$ \\
\hline $\begin{array}{l}\text { M. domestica, } \\
\text { H. illucens }\end{array}$ & West Africa & $\begin{array}{l}\text { Life cycle inventory assessment of rearing M. domestica } \\
\text { and } H \text {. illucens on chicken and sheep manure for feed. }\end{array}$ & $\begin{array}{l}\text { Roffeis et al. } \\
\text { (2017) }\end{array}$ \\
\hline $\begin{array}{l}\text { G. bimaculatus, } \\
\text { A. domesticus }\end{array}$ & Thailand & LCA of two cricket species reared on pumpkins for food. & $\begin{array}{l}\text { Halloran et al. } \\
\text { (2017) }\end{array}$ \\
\hline L. terrestris & Italy & $\begin{array}{l}\text { LCA of a small-scale production system of earthworms } \\
\text { for food/feed. }\end{array}$ & $\begin{array}{l}\text { Tedesco et al. } \\
\text { (2019) }\end{array}$ \\
\hline
\end{tabular}


Given the recent increase in the interest of insects for human food in Europe, such companies are receiving growing numbers of enquiries regarding insect-based products for the human food industry. As a result, some are considering taking advantage of this new business opportunity by converting some of their production capacity from live pet food into production for human food. However, the production of insects for human consumption is not the same as production for live pet food, as described later in this paper (Section 6.3): it is not clear at present whether the existing practices are appropriate for both business models, or whether new practices need to be adopted. Therefore, it is not possible to judge whether a shift in business model from live pet food to a hybrid live pet food/ human food business model is an environmentally beneficial way forward.

This study presents an LCA of rearing crickets for the live pet food market. A case study approach is used, based on a commercial insect farm in the UK that is currently producing crickets for the live pet food market, and seeking to enter the human food market. A cradle-to-farm-gate LCA of the current production process is presented, and, based on this, ways in which the current environmental impacts may be reduced are investigated, and the implications of introducing production for human food are discussed.

The objectives of this study are therefore to:

i) Assess the environmental impacts of rearing crickets for the live pet food market in the UK;

ii) Compare these results with those found in Halloran et al. (2017). Although Halloran et al.'s study reports an LCA of rearing crickets for human consumption and the current study reports an LCA of rearing crickets for the live pet food market, useful outcomes can nevertheless be achieved;

iii) Explore how improvements in current rearing practices on the case study farm may reduce environmental impacts;

iv) Explore if environmental benefits can be achieved through combining production of live pet food with production for human food in a hybrid business model.

The paper is organized as follows. An overview of the case study farm and details of the LCA method are presented in Section 2. The life cycle inventory is presented in Section 3. The LCA results and sensitivity analysis of the impact assessment are discussed in Section 4. Section 5 uses scenario analysis to explore ways to reduce environmental impacts and the implications of the introduction of production for human consumption. Drawing on the LCA and scenario analysis results, Section 6 discusses improvements in rearing practices that may reduce the environmental impacts of the current production process, and the potential benefits of introducing production for human food. Section 6 concludes with a discussion of the limitations of this study. Concluding remarks are given in Section 7. Where necessary, further data are available in the Supplementary Information. Tables in the Supplementary Information are referred to with the prefix "S".

\section{Methodology of LCA of cricket production for live pet food market}

This article presents an attributional cradle-to-farm-gate LCA for rearing the cricket species G. bimaculatus and G. sigillatus for the live pet food market on a case study insect farm based in the south east UK over the timeframe 2016 to 2017.

\subsection{Overview of the case study cricket farm}

The farm produced $12.46 \mathrm{t} \mathrm{G}$. bimaculatus and G. sigillatus for the live pet food market in a variety of sizes over the period 2016/17. They are raised in a converted agricultural barn, which predated the arrival of the insect farm. The land area of the barn is approximately $1120 \mathrm{~m}^{2}$ and contains all facilities necessary for rearing and processing the crickets for shipping to retailers. ${ }^{1}$ The internal space is divided into multiple rooms, of which 12 are used for rearing crickets. Each room is insulated with rockwool and can be sealed to allow effective climate control. Heated air is provided from a biomass heater, which is located in a separate building. The air is ducted into each room and the flow adjusted to control temperature. The heated air is flushed through the building once before being vented to the atmosphere. No heat recovery is applied. A 50$\mathrm{kWp}$ solar photovoltaic array is located on the grounds and supplies electricity to the site. Lighting is provided by fluorescent tube strip lights.

The insect farm also produces a total of $76.1 \mathrm{t} /$ year silent crickets (G. assimilis) and locusts (S. gregaria) for the live pet food market. These are not included in the LCA as, due to the case study farm's current production processes, these species are not under consideration for rearing for the human food market. The locusts are reared in multiple buildings on the main farm site, with some reared in the barn described previously. The silent crickets are reared on an entirely separate, second site.

The farm developed gradually over time, with new infrastructure added as required. Because of this, utilities such as water, electricity, and heat are supplied to the site as a whole, with separate meters monitoring each utility. Therefore, allocation of impacts needs to account for aggregated utility measurements. Furthermore, 6 members of staff live on-site, so

\footnotetext{
${ }^{1}$ Processing of the crickets for shipping to retailers involves separating the crickets into batches of a given number of individuals. The crickets are placed, alive, into a plastic box along with a piece of egg card and some sawdust (details in Section 3.2). The number of crickets in each batch is dependent upon the size at which they are harvested.
} 
assumed energy and water use of those staff needs to be subtracted from the data collected on-site.

\subsection{System boundaries and life cycle inventory}

The LCA system boundary is shown in Fig. 1. It is cradle-tofarm-gate and includes all inputs for rearing the crickets (utilities and heating; materials used in the construction of the buildings, attributable over the lifetime of use; cricket feed production; consumables such as cardboard boxes for housing crickets during the rearing process and peat used as an egg laying substrate); cricket processing for export from the farm to retailers (including use of packaging materials); emissions to air; discarded consumables; and "frass." Technically frass is just insect feces, but in this context, it is broadened to include all loose organic material that remains after the crickets have been harvested. The frass is applied to the land, which leads to reduced use of other mineral fertilizers (avoided fertilizers). To facilitate comparison with the only other known LCA of crickets, the system boundaries align as far as possible with those used in Halloran et al. (2017), which assesses the rearing and processing of crickets for human food. Both studies are cradle-to-farm-gate, excluding downstream activities such as retail and consumption. Figure 1 contains the same life cycle phases as used in Halloran et al. (2017), except with terminology more appropriate for this study. It should be noted that the cricket processing methods differ between studies. In Halloran et al. (2017), crickets are prepared for human consumption, whereas in this study, the crickets are prepared for export from the farm while still alive. To facilitate comparison prior to the processing step, environmental impacts are reported in this paper according to life cycle phase.

The LCA was conducted in SimaPro 8.4. Primary data were collected on-site over the course of late 2017 and early 2018, with data taken from 2016/17 financial year business records where complete annual records were required. Where information could not be recorded first hand, background data were taken from the EcoInvent 3.3 database (for details, see Supplementary Information).
To assess the impact upon the environment, the International Reference Life Cycle Data System (ILCD) 2011 Midpoint+ suite of environmental impact categories was used. Within that, particular focus is given in this manuscript to climate change, ozone depletion, particulate matter, acidification, freshwater eutrophication and ecotoxicity, land use, and water resource depletion. The full set of ILCD 2011 midpoint impact categories as reported by SimaPro are included in the supplementary information (see Section 4 and Table S6).

\subsection{Comparison study}

The results of this study are compared to Halloran et al. (2017) which reported the environmental impact of a cricket farm in north-eastern Thailand. Halloran et al's case study farm produces $36.7 \mathrm{t}$ /year of crickets ( $17.8 \mathrm{t}$ /year of G. bimaculatus and $19.0 \mathrm{t} / \mathrm{year}$ of A. domesticus) for human food. The crickets are reared on broiler chicken feed and pumpkins in large open pens with no climate control. Their study included a processing stage in preparation for retail (the details of which are taken from a wholesaler and not disclosed beyond resource inputs) but excluded further downstream processes, such as cooking. Application of the frass to land is included to understand the potential to use it to displace mineral fertilizers. Halloran et al's results are presented in terms of two functional units ( $1 \mathrm{~kg}$ edible mass and $1 \mathrm{~kg}$ protein), and compared to the impacts of rearing equivalent functional units of broiler chicken meat.

\subsection{Functional unit}

A functional unit of $1 \mathrm{~kg}$ edible mass of crickets (G. bimaculatus and G. sigillatus) is used, as in Halloran et al. (2017). However, for the current study, the crickets are still alive when exported from the farm, and in Halloran et al. (2017) they are not. When consumed as live pet food, 100\% of the cricket is eaten by the pet. The crickets are shipped from the farm in batches of a given number, as opposed to fixed mass. By using mass as the functional unit,
Fig. 1 System boundary of the cricket production process

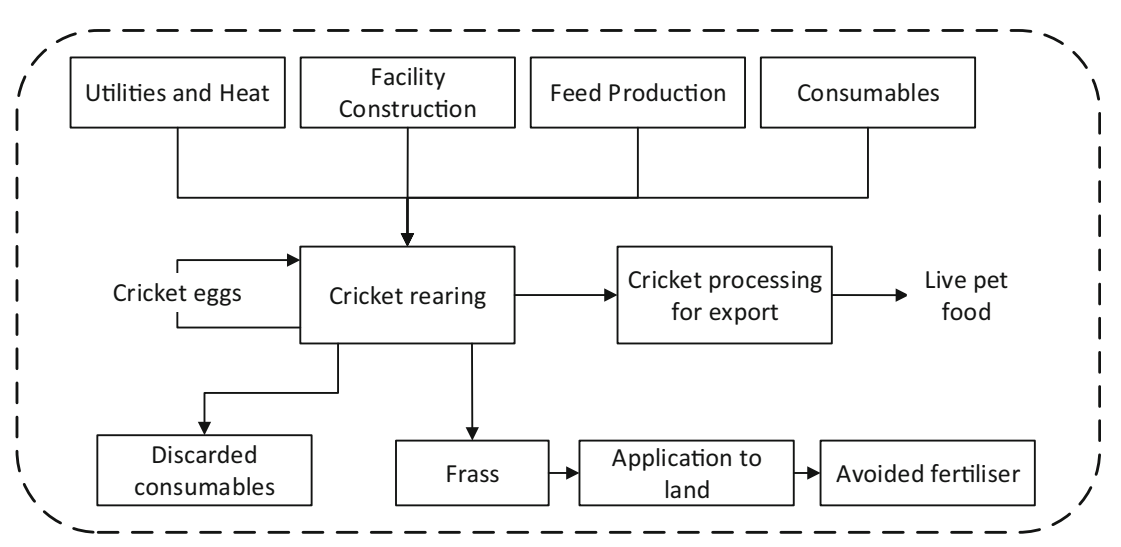


comparison can more readily be made to Halloran et al. (2017) and any future studies regarding rearing crickets. The method for ascertaining the live shipped mass is outlined in Section 3.4.

\subsection{Allocation}

Due to the choice of mass as a functional unit, mass allocation is used throughout this study. It is used in instances when it is not possible to clearly define how much input is consumed by each species. This is true of peat, utilities, heat, and building materials used. Relevant equations are given in Supplementary Information, Section 2.

Peat is used by all four species reared by the business. G. sigillatus and G. bimaculatus make up $12.46 \mathrm{t} /$ year of $88.57 \mathrm{t} /$ year total insect production from all farm sites (i.e., 14.1\%), and so $14.1 \%$ of consumed peat mass is allocated to these species. With respect to utilities, heat, and building materials, impacts need to be assigned to species reared on the same site. G. bimaculatus and G. sigillatus make up $12.46 \mathrm{t} /$ year of total 66.89 t/year of G. bimaculatus, G. sigillatus, and S. gregaria reared on the same site (i.e., $18.6 \%$ ), and so $18.6 \%$ is allocated to these species. This allocation excludes G. assimilis as they are reared at a separate site and do not share the utilities, heat, or buildings. With respect to avoided impacts, system expansion is used to include the effect of using frass as a replacement for mineral fertilizer.

\subsection{Elemental measurement methods}

Where data were not available, mass balance calculations were used to calculate material flows and nutrient throughput. Samples of the feed and frass were taken in order to assess quantities of nitrogen $(\mathrm{N})$, potassium $(\mathrm{K})$, phosphorus $(\mathrm{P})$, and carbon $(\mathrm{C})$ within them. Prior to each measurement, the samples were dried, until only the dry matter (DM) of each of the samples remains. Reported quantities of CNPK in this study are thus given in percentages of the respective dry matter.

Measurements of elemental carbon (C) and nitrogen $(\mathrm{N})$ were made using an Exeter Analytical CE-440 elemental analyzer. Measurement of elemental potassium $(\mathrm{K})$ composition required conversion of the sample to ash, diluting in $5 \mathrm{ml}$ concentrated nitric acid, further diluting up to a volume of $50 \mathrm{ml}$ with de-ionized water and analysis with a Dionex ICS5000 ion chromatograph (CS16 divinylbenzene based cation exchange column, methanesulfonic acid eluent, conductivity tester). Preparation of samples for elemental phosphorus (P) measurement was the same as for $\mathrm{K}$, but with an additional 100 -fold dilution of the $50 \mathrm{ml}$ liquid sample, followed by testing with AquaChek phosphate specific dipsticks.

\section{Life cycle inventory of cricket production for live pet food market}

All main data used within the LCA are summarized in Table 2 and explained in this section.

\subsection{Input: feed}

Both G. bimaculatus and G. sigillatus are fed on commercially available chicken feed, with $113.28 \mathrm{t} /$ year consumed. Feed conversion ratio (FCR) is a key metric: it is defined here as the mass of feed in kilograms required to rear $1 \mathrm{~kg}$ of crickets. The total live shipping mass of G. bimaculatus and G. sigillatus was $12.46 \mathrm{t} / \mathrm{year}$, and hence, the average FCR for the two species across all harvested sizes is 9.09:1. No life cycle data exists for the feed in the EcoInvent database; therefore, it is approximated by using appropriate analogues for each ingredient in the quantities as defined on the feed packaging (see Table S1).

\subsection{Input: consumables}

Consumables in this context are those items which are used only once per cricket rearing cycle. Quantities used for G. bimaculatus and G. sigillatus are given in Table 2 within the groups "consumables (rearing)" and "consumables (shipping)". Consumables used during rearing are cardboard boxes in which batches of crickets are housed while they grow (19.22 t/year) and cardboard egg trays which are placed inside the boxes to increase the living surface area (14.04 t/year). Both are discarded and sent for recycling after a single use to prevent spread of disease. Peat is used as an egg laying substrate for all four insect species during breeding and this is also discarded at the end of the rearing cycle. The business purchases $123.75 \mathrm{t} /$ year peat, but records of how much was used per species were not kept; therefore, it is assumed that $14.1 \%$ of all peat is used by G. bimaculatus and G. sigillatus (17.45 t/year, as per the allocation described in Section 2.5). No cleaning is performed on either the consumables, crickets, or rooms during or between batches. Therefore, it is assumed that no cleaning products are used, and thus, it is not included in the LCA.

For live shipping, low-density polyethylene (LDPE) plastic containers are used (14.44 t/year), into which a small piece of cardboard egg tray is placed (approx. $3.28 \mathrm{t} /$ year) and some sawdust (approx. $4.19 \mathrm{t} /$ year). No feed is placed in the boxes. The mass of cardboard egg tray used for shipping is in addition to the egg tray used during rearing. The quantities are given as approximate because sample shipping boxes were taken for weighing; however, precise masses of egg tray and sawdust used in the containers may vary over the course of the year. These are shipped to pet shops and are not returned. 
Table 2 Main inventory data relating to the life cycle of rearing and shipping crickets for year 2016/2017. Tables S1-S5 are in the Supplementary Information. Inventory data are reported in the same units used by the relevant EcoInvent database entries

\begin{tabular}{|c|c|c|c|c|c|}
\hline Group & Item & Amount & Unit & Source & Further information \\
\hline \multirow{4}{*}{$\begin{array}{l}\text { Consumables } \\
\text { (rearing) }\end{array}$} & Feed & 113.28 & t/year & On-site data & Table S1 \\
\hline & Cardboard boxes & 19.22 & t/year & On-site data & Table S2 \\
\hline & Cardboard egg tray & 14.04 & t/year & On-site data & Table S2 \\
\hline & Peat & 17.45 & t/year & On-site data & Table S2 \\
\hline \multirow[t]{3}{*}{$\begin{array}{c}\text { Consumables } \\
\text { (shipping) }\end{array}$} & $\begin{array}{l}\text { Low-density } \\
\text { polyethylene } \\
\text { (LDPE) boxes }\end{array}$ & 14.44 & t/year & $\begin{array}{l}\text { On-site } \\
\text { measurement }\end{array}$ & Table S2 \\
\hline & Cardboard egg tray & 3.28 & t/year & $\begin{array}{l}\text { On-site } \\
\text { measurement }\end{array}$ & Table S2 \\
\hline & Sawdust & 4.19 & t/year & $\begin{array}{l}\text { On-site } \\
\text { measurement }\end{array}$ & Table S2 \\
\hline Buildings & Various items & & & $\begin{array}{l}\text { On-site } \\
\text { assessment }\end{array}$ & Table S5 \\
\hline \multirow[t]{4}{*}{ Utilities } & Electricity & 202.83 & MWh/year & On-site data & Table S4 \\
\hline & Heat & 156.85 & MWh/year & On-site data & \\
\hline & Water & 1336.47 & $\mathrm{~m}^{3} /$ year & Calculated & \\
\hline & Solar & 8.93 & MWh/year & Calculated & \\
\hline \multirow{3}{*}{$\begin{array}{l}\text { Transport from } \\
\text { supplier to } \\
\text { farm site }\end{array}$} & Feed & 73.6 & $\mathrm{~km}$ & Calculated & \\
\hline & Peat & 290 & $\mathrm{~km}$ & Calculated & \\
\hline & $\begin{array}{l}\text { Cardboard egg tray } \\
\text { \& boxes }\end{array}$ & 60.8 & $\mathrm{~km}$ & Calculated & \\
\hline \multirow[t]{4}{*}{ Crickets } & G. sigillatus & 2.48 & t/year & On-site data & \\
\hline & G. bimaculatus & 9.98 & t/year & On-site data & \\
\hline & $\begin{array}{l}\mathrm{CO}_{2} \text { from } \\
\text { respiration }\end{array}$ & 16.4 & t/year & $\begin{array}{l}\text { Halloran et al. } \\
\text { (2017) }\end{array}$ & $\begin{array}{c}1.32 \mathrm{kgCO}_{2} / \mathrm{kg}_{\text {cricket }} \\
\text { per rearing cycle }\end{array}$ \\
\hline & $\mathrm{NH}_{3}$ & 1.02 & t/year & DEFRA (2014) & \\
\hline \multirow[t]{5}{*}{ Frass } & Mass & 107.52 & t/year & Calculated & \\
\hline & $\mathrm{CO}_{2}$ emitted & 137 & t/year & Calculated & \\
\hline & Avoided N & 5.13 & t/year & $\begin{array}{l}\text { On-site } \\
\quad \text { measurement } \\
+ \text { calculation }\end{array}$ & Table S3 \\
\hline & Avoided P & 9.43 & t/year & $\begin{array}{l}\text { On-site } \\
\text { measurement } \\
+ \text { calculation }\end{array}$ & Table S3 \\
\hline & Avoided K & 2.86 & t/year & $\begin{array}{l}\text { On-site } \\
\text { measurement } \\
+ \text { calculation }\end{array}$ & Table S3 \\
\hline
\end{tabular}

\subsection{Input: utilities}

Electricity is supplied to the site both from the UK national grid and from the 50-kWp solar photovoltaic (PV) groundbased array located on-site. The total annual input from the grid is measured at a single meter (1127.9 MWh/year). However, 6 staff live on-site and there are two walk-in freezers which are not part of the cricket rearing process; therefore, the net electricity demand is assumed to be 1090.5 MWh/year (see Table 3 for details of calculations). The GHG emissions related to electricity taken from the grid are calculated by updating an outdated EcoInvent process with UK grid mix data for 2016 (BEIS 2018a). The resulting emissions are calculated to be $0.418 \mathrm{kgCO}_{2}-\mathrm{eq} / \mathrm{kWh}$, which is in line with UK data for $2016\left(0.412 \mathrm{kgCO}_{2}\right.$-eq/kWh, (BEIS 2016)). See Table $S 4$ for details of the grid mix.

The total output in terms of $\mathrm{kWh}$ from the on-site solar panels is not known, but the National Renewable Energy Laboratory (NREL) gives an estimate for $960 \mathrm{kWh} / \mathrm{kWp}$ for a solar PV system installed at the farm's location (NREL 2018). It is assumed that all of the $48 \mathrm{MWh} /$ year generated is used on-site.

Water is abstracted from the mains through a single meter to the entire site. A gross total of $7492.2 \mathrm{~m}^{3} /$ year is abstracted in the form of potable water. As mentioned above, the 6 staff living on-site will be responsible for some of this consumption; therefore, it is assumed that the amount used by the farm is $7172.5 \mathrm{~m}^{3} /$ year (see Table 3). The fate of the water used by 
Table 3 Allocation of consumption of electricity and water to insect rearing across the entire site

\begin{tabular}{lrlll}
\hline Item & Quantity & Unit & Details & Source \\
\hline Gross electricity consumption of entire site & 1127.9 & MWh/year & Measured at meter & Data from site \\
Electricity allocated to staff living on-site & 8.83 & $\begin{array}{l}\text { MWh/year } \\
\text { 2 households each consuming 4.42 MWh/year }\end{array}$ & BEIS (2018b) \\
$\begin{array}{l}\text { Electricity used by 2 walk-in freezers (not used } \\
\quad 28.62\end{array}$ & $\begin{array}{l}\text { MWh/year } \\
\text { for insect production) }\end{array}$ & $\begin{array}{l}\text { 2 freezers each consuming } \\
\text { 39.2 kWh/day }\end{array}$ & Mudie et al. (2016) \\
Net electricity consumption for rearing insects & 1090.5 & $\begin{array}{l}\text { MWh/year } \\
\text { Gross water consumption }\end{array}$ & & Calculation \\
Water consumed by staff living on-site & 7492.2 & $\mathrm{~m}^{3} /$ year & Measured at meter & Data from site \\
Net water consumption & 319.7 & $\mathrm{~m}^{3} /$ year & 6 staff using 146 1/day each & Walsh et al. (2016) \\
\hline
\end{tabular}

the farm is not known: no cleaning is conducted of the cricket rearing rooms, and no evidence was provided for cleaning elsewhere. Hence, only the production of the water is included in the study; waste water treatment is excluded as it is assumed that it soaks into the ground or evaporates.

Heat to the farm site is provided by a wood chip biomass heater, which uses softwood as a fuel, and produces 843.3 MWh/year of heat energy.

As the utilities are supplied to the whole site, the appropriate quantities attributed to insect rearing must be attributed to G. bimaculatus and G. sigillatus, compared to S. gregaria, which is $18.6 \%$ of the total (see Section 2.5). Therefore, net consumption of the two species of cricket is assumed to be mains electricity 202.83 MWh/year, solar PV electricity 8.93 MWh/year, heat 156.85 MWh/year, and water $1334.09 \mathrm{~m}^{3} /$ year (Table 2).

\subsection{Output: crickets and processing for export}

The growing period of the crickets in this system is approximately 42 days for $\mathrm{G}$. bimaculatus and 67 days for $\mathrm{G}$. sigillatus from eggs being laid to the largest size shipped. However, this does not relate to how the crickets are shipped out from the farm. The live pet food industry requires crickets of varying sizes, depending upon the animal to which the crickets are to be fed. Therefore, the farm ships out batches containing a given number of crickets in a range of different size bands, harvested at different ages. The different size ranges of crickets are treated as one output from the farm in this LCA study. This is because the input materials and utilities are aggregated across all sizes and it is not possible to distinguish between what is used for each size band. In order to calculate the aggregated shipped mass of crickets, 10 samples from each size band were weighed and the average individual cricket mass calculated. This mass combined with the number of crickets sold over the course of a year gives the total mass of crickets shipped. The annual shipped mass was G. sigillatus $2.48 \mathrm{t}$ and $\mathrm{G}$. bimaculatus $9.98 \mathrm{t}$, giving a total mass of $12.46 \mathrm{t}$ /year.

\subsection{Output: frass}

The frass is collected by another local farmer and used as a soil supplement. The quantity of frass generated is not measured by the cricket farm. Instead, it is calculated here by a mass balance of the dry matter within all of the relevant inputs (feed, peat) and outputs (shipped crickets and $\mathrm{CO}_{2}$ emissions from cricket respiration) during the rearing process. The dry matter fraction within each material was measured from samples taken from the site, and results shown in Table 4. The total annual production of frass dry matter is found to be $98.49 \mathrm{t}_{\mathrm{DM}} / \mathrm{year}$, which equates to $107.52 \mathrm{t} /$ year wet mass, or $8.63 \mathrm{~kg} / \mathrm{kg}_{\text {cricket }}$ (the equation for this calculation is in Supplementary Information, Section 2, with cricket respiration data in Section 3.8).

It is assumed that the nitrogen, phosphorus, and potassium (NPK)-based nutrients within the frass can displace the equivalent mass of mineral NPK fertilizers. Therefore, in order to ascertain the potential for frass to replace mineral fertilizers, elemental analysis was performed to determine the masses of NPK within the frass. Separate frass samples for elemental analysis were taken for both G. bimaculatus and G. sigillatus. The quantity of each of NPK was measured, as per the processes outlined in Section 2.5. The results of the measurements are shown in Table 4. The result is given as the percent of the element present within the dry matter of the frass, which is used to calculate the total mass of that nutrient within the frass when spread to land. The results of the analysis are shown separately for the frass from G. bimaculatus and G. sigillatus. However, the frass from both species are mixed together prior to shipping from the farm. Therefore, during the environmental analysis, the fractional content of NPK in the samples was calculated as an average which is weighted by mass of each cricket species shipped from the farm. These averaged NPK fractions are also shown in Table 4.

The fractional content of dry matter within the frass, combined with the fractions of NPK within that dry matter, is used to calculate the avoided burden of producing the equivalent mass of mineral-based NPK fertilizers. This yields calculated replaced quantities of fertilizer of 5.13 t/year for nitrogen, 
Table 4 Percentage dry matter within samples and elemental composition of the dry matter in feed, peat, cricket, and frass. Elemental composition data given for carbon, nitrogen, phosphorus, and potassium

\begin{tabular}{llllll}
\hline & Item & $\begin{array}{l}\text { G. bimaculatus } \\
(\% \text { of total mass })\end{array}$ & $\begin{array}{l}\text { G. sigillatus } \\
(\% \text { of total mass })\end{array}$ & $\begin{array}{l}\text { Average } \\
(\% \text { of total mass })\end{array}$ & Source \\
\hline Feed & Dry matter & - & - & 89.5 & Sample from site \\
Peat & Dry matter & - & - & 27.3 & Sample from site \\
Crickets & Dry matter & - & - & 26 & Halloran et al. (2017) \\
Frass & Dry matter & 91.1 & 93.3 & 91.6 & Sample from site \\
& & $(\%$ of DM $)$ & $(\%$ of DM $)$ & $(\%$ of DM $)$ & Sample from site \\
Feed & Carbon & - & - & 43.3 & Sample from site \\
& Nitrogen & & - & 4.4 & Sample from site \\
Peat & Carbon & - & - & 54.6 & Halloran et al. (2017) \\
Crickets & Carbon & - & 36.7 & 38.7 & Sample from site \\
Frass & Carbon & 39.2 & 7.1 & 5.2 & Sample from site \\
& Nitrogen & 4.7 & 1.8 & 2.1 & Sample from site \\
& Phosphorus & 2.2 & 3.1 & 2.4 & Sample from site \\
\hline
\end{tabular}

$9.43 \mathrm{t} /$ year for phosphorus, and $2.86 \mathrm{t} /$ year for potassium (see Table 2 and Table S3). Individual elemental fertilizers are used as the ratios of the elements within the frass do not match other fertilizers available in the SimaPro databases. It is further assumed that the frass creates equivalent environmental impacts to the mineral based fertilizers after it is spread to land (such as emissions of nitrous oxide, or eutrophication), and so, these are not included in this assessment. Emissions of ammonia from the frass, after it has been removed from the cricket rearing process and prior to application to the land, are assumed to be zero as it is very dry, with the majority of ammonia being lost within the rearing rooms. Upon application to land, the ammonia emissions are assumed to be the same as an applied mineral fertilizer and are also omitted from this LCA. Changes in transportation distance of any offset mineral fertilizer to the frass are not accounted for. All of these values may be subject to a sampling error, due to the fact that the frass is made of multiple materials (peat, feed, feces, etc) leading to variation between samples. This is particularly true for the phosphorus, as the measurement method itself has an error of approximately $\pm 0.7 \%$ (compared to an average measured value of $2.1 \%$, Table 4 ). (The particular method was chosen due to difficulties discerning phosphates from nitrates in the other available measurement techniques.) Therefore, carbon, nitrogen, phosphorus, and potassium measurement values were tested in a sensitivity analysis, as described in Section 4.1.

\subsection{Facilities and buildings}

The farm comprises buildings and surrounding hard standing, all of which are utilized in some way for the cricket rearing. Details of the estimated quantities of materials used for both the buildings and the hard standing are given in Table 5. The units are given as per the representative EcoInvent database entry, and details of these may be found in Table S5.
The lifetime of the buildings is assumed to be 25 years and it is also assumed that the cricket farm business is responsible for the entire construction and use of the buildings throughout that time. This is not the case; the barn preceded the cricket farm, and new structures were added over time. However, given that no records exist of exactly what was constructed when, 25 years is chosen as an indicative lifetime. G. bimaculatus and G. sigillatus are allocated $18.6 \%$ of the total impact associated with the materials used in the buildings (the rest being attributed to S. gregaria, see Section 2.5).

\subsection{Transportation}

Transportation of feed, peat, and cardboard from suppliers to the farm is assumed to be by 32 ton (EURO5) articulated lorry for regional transport. The transport distance for inputs is taken as the distance between the supplier and the farm. Transport of raw materials from producers to the suppliers themselves is assumed to be contained within the individual

Table 5 Materials used in the construction of all buildings on the cricket farm site

\begin{tabular}{ll}
\hline Material & Quantity \\
\hline Concrete for flooring & $360.6 \mathrm{~m}^{3}$ \\
Hard-core for outside areas & $168.00 \mathrm{t}$ \\
Asbestos building cladding & $87.81 \mathrm{t}$ \\
Corrugated tin cladding & $5949.1 \mathrm{~m}^{2}$ \\
Bricks & $75.60 \mathrm{t}$ \\
Light weight concrete blocks & $36.00 \mathrm{t}$ \\
Structural wood (plywood) & $17.6 \mathrm{~m}^{3}$ \\
Structural wood (joists) & $3861.4 \mathrm{~m}$ \\
Structural steel (as RSJ) & $19.07 \mathrm{t}$ \\
Insulation materials & $7.53 \mathrm{t}$ \\
Lifetime of buildings & 25 years (assumed) \\
\hline
\end{tabular}


materials processes, and modelled using the "market for" processes within EcoInvent.

\subsection{Emissions to air}

Cricket respiratory emissions were not measured as part of this LCA. However, crickets do breathe and the respiratory $\mathrm{CO}_{2}$ emissions cannot be ignored. The Halloran et al. (2017) study reported that $1 \mathrm{~kg}$ of crickets produced $1.3165 \mathrm{~kg} \mathrm{CO}_{2}$ over a rearing cycle, and this value is used in the current study. Halloran et al. carried out further emissions tests for $\mathrm{N}_{2} \mathrm{O}$ and $\mathrm{CH}_{4}$, but these were found to be insignificant over the course of a year and are therefore ignored in both studies.

Emissions of ammonia $\left(\mathrm{NH}_{3}\right)$ from cricket production are calculated in a similar manner to Halloran et al. (2017) who assumed conditions for rearing crickets may be considered similar to that for broiler chickens, as they are fed a similar type of feed. Based on Webb and Misselbrook (2004), who estimated ammonia emissions from broiler livestock buildings to be equivalent to $21 \%$ of all nitrogen which enters the building in the feed, we use an estimate of $0.082 \mathrm{kgNH}_{3}$ per $1 \mathrm{~kg}$ crickets produced.

It is assumed that all of the carbon within the frass is emitted to the atmosphere as $\mathrm{CO}_{2}$ when spread upon the land and that none is sequestered. The mass of $\mathrm{CO}_{2}$ emitted is calculated from the quantity of carbon within the dry matter of the frass (Table 4). While this will give a maximum possible emission factor for the frass, it may over-estimate true emissions, as some may be sequestered (Boldrin et al. 2009), especially given the presence of peat in the frass (Oldfield et al. 2018).

\subsection{Losses and overproduction of crickets}

In addition to the measured cricket production quantities, there are two causes of overproduction which are included within the resource requirements, but are not recorded. The first comes from "hoppage," the term used by the business to denote those insects that escape during the rearing process. Anecdotally, the business considers this to be a very small fraction of all production, and is insignificant enough that steps taken to prevent it are considered too costly and not worthwhile implementing.

The second is as a result of the needs of the live pet food industry: pet shops require a reliable supply of healthy, living crickets. Therefore, an excess of crickets is produced so that there is no possibility of a short fall in the amount required to

\footnotetext{
2 "Market for" processes are provided in the EcoInvent database for instances when the exact provenance of a material is not known. They include assumed contributions of different materials supplied from around the world and associated approximate shipping distances.
}

meet the orders. Part of the need for overproduction is to protect the business against population decrease through spread of disease. No antimicrobial treatments are used to mitigate against disease, only controls such as the aforementioned disposal of cardboard boxes and peat. The overproduction is not measured by the company, only the amount sold, but the resources consumed by the excess crickets are still kept in the inventory data and thus accounted for in this LCA. The unwanted crickets are discarded.

\section{Results of LCA of cricket production for live pet food market, and sensitivity analysis}

This section presents the results of the LCA, followed by a sensitivity analysis. The midpoint environmental impacts of rearing crickets for the live pet food market are shown in Table 6, and the percentage contribution of each life cycle phase to the total is shown in Fig. 2. The results show that in general, the sources of greatest impact are feed production and the rearing processes. This is true for all impact categories shown in Table 6, with the exception of climate change which has the greatest contribution from the rearing process and frass application.

Feed production accounts for the greatest impact within water resource depletion $\left(0.810 \mathrm{~m}^{3} \mathrm{H}_{2} \mathrm{O}\right.$-eq $/ \mathrm{kg}_{\text {cricket }}$ out of $0.817 \mathrm{~m}^{3} \mathrm{H}_{2} \mathrm{O}$-eq $/ \mathrm{kg}_{\text {cricket }}$ ), land use change (128 kgC-deficit/ $\mathrm{kg}_{\text {cricket }}$ out of $157 \mathrm{kgC}$-deficit $/ \mathrm{kg}_{\text {cricket }}$ ), freshwater eutrophication $\left(4.96 \times 10^{-3} \mathrm{kgP}-\mathrm{eq} / \mathrm{kg}_{\text {cricket }}\right.$ out of $5.75 \times 10^{-3} \mathrm{kgP}$-eq/ $\left.\mathrm{kg}_{\text {cricket }}\right)$, freshwater ecotoxicity (118 CTUe/ $\mathrm{kg}_{\text {cricket }}$ out of $\left.162 \mathrm{CTUe} / \mathrm{kg}_{\text {cricket }}\right)$, and ozone depletion $(1.24 \times$ $10^{-6} \mathrm{kgCFC}-11$-eq $/ \mathrm{kg}_{\text {cricket }}$ out of $1.79 \times 10^{-6} \mathrm{kgCFC}-11$-eq/ $\left.\mathrm{kg}_{\text {cricket }}\right)$. For each of these impact categories, the rearing phase is the second biggest contributor to environmental impact.

The rearing process is the largest contributor for particulate matter $\left(1.01 \times 10^{-2} \mathrm{kgPM} 2.5-\mathrm{eq} / \mathrm{kg}_{\text {cricket }}\right.$ out of $2.04 \times$ $\left.10^{-2} \mathrm{kgPM} 2.5-\mathrm{eq} / \mathrm{kg}_{\text {cricket }}\right)$ : this is due to the use of biomass heating. Similarly, the rearing process is the most significant contributor for acidification potential $(0.284 \mathrm{molcH}+\mathrm{eq} / \mathrm{kg}$ cricket out of $0.342 \mathrm{molcH}+\mathrm{eq} / \mathrm{kg}_{\text {cricket }}$ ). For both these impact categories, the next most significant life cycle phase is feed production.

Climate change potential is an exception to the above. The rearing phase is the greatest contributor to overall impact (12.4 $\mathrm{kgCO}{ }_{2}$-eq $/ \mathrm{kg}_{\text {cricket }}$ out of $21.1 \mathrm{kgCO}{ }_{2}$-eq $/ \mathrm{kg}_{\text {cricket }}$ ), of which heating accounts for $3.71 \mathrm{kgCO}$-eq/ $\mathrm{kg}_{\text {cricket }}$. However, in contrast to the other impact categories, the next most significant life cycle phase is application of frass to land (11 $\mathrm{kgCO}_{2}$-eq $\left./ \mathrm{kg}_{\text {cricket }}\right)$ due to the assumed conversion of biotic carbon to $\mathrm{CO}_{2}$, followed by processing for export $\left(3.26 \mathrm{kgCO}_{2}\right.$-eq $\left./ \mathrm{kg}_{\text {cricket }}\right)$. Feed production is the fourth largest 
Table 6 Comparison of ILCD 2011 Midpoint+ environmental impacts resulting from rearing and shipping of $1 \mathrm{~kg}$ live crickets from the farm site: $1 \mathrm{~kg}$ crickets, as shipped ("total"), given with breakdown of important life cycle data; comparison to Halloran et al. (2017) (column in italics). Further impacts shown as a function of impact category and notable phases. Abbreviations are as follows: "Construct" building construction, "Feed Prod." feed production, "Frass Appl." frass application to the land, and "Avoided Fert." avoided fertilizers. "Rearing" includes all the inputs required to raise the crickets, such as heating, water, electricity, and also includes cricket respiration

\begin{tabular}{|c|c|c|c|c|c|c|c|c|c|}
\hline Impact Category & $\begin{array}{l}\text { Total per kg } \\
\text { cricket } \\
\text { shipped }\end{array}$ & Construct & Transport & Feed Prod. & $\begin{array}{l}\text { Rearing (of } \\
\text { which due } \\
\text { to heating) }\end{array}$ & $\begin{array}{l}\text { Processing } \\
\text { for export }\end{array}$ & $\begin{array}{l}\text { Frass } \\
\text { Appl. }\end{array}$ & $\begin{array}{l}\text { Avoided } \\
\text { Fert. }\end{array}$ & $\begin{array}{l}\text { Halloran et al. } \\
\text { 2017) total } \\
\text { per kg } \\
\text { shipped }\end{array}$ \\
\hline $\begin{array}{l}\text { Climate change } \\
{\left[\mathrm{kgCO}_{2} \text {-eq] }\right.}\end{array}$ & 21.1 & 0.148 & 0.180 & 0.348 & $\begin{array}{l}12.4 \\
(3.71)\end{array}$ & 3.26 & 11.0 & -6.27 & 2.57 \\
\hline $\begin{array}{l}\text { Ozone depletion } \\
\text { [kgCFC-11-eq] }\end{array}$ & $1.79 \times 10^{-6}$ & $1.54 \times 10^{-8}$ & $3.36 \times 10^{-8}$ & $1.24 \times 10^{-6}$ & $\begin{array}{l}8.73 \times 10^{-7} \\
\left(5.30 \times 10^{-8}\right)\end{array}$ & $1.01 \times 10^{-7}$ & 0 & $-4.71 \times 10^{-7}$ & $1.3 \times 10^{-7}$ \\
\hline $\begin{array}{l}\text { Particulate matter } \\
\text { [kgPM2.5-eq] }\end{array}$ & $2.04 \times 10^{-2}$ & $2.12 \times 10^{-4}$ & $9.39 \times 10^{-5}$ & $6.06 \times 10^{-3}$ & $\begin{array}{l}1.77 \times 10^{-2} \\
\left(1.01 \times 10^{-2}\right)\end{array}$ & $2.15 \times 10^{-3}$ & 0 & $-5.85 \times 10^{-3}$ & $5.0 \times 10^{-3}$ \\
\hline $\begin{array}{l}\text { Acidification } \\
{[\text { molcH+eq] }}\end{array}$ & 0.342 & $1.22 \times 10^{-3}$ & $7.57 \times 10^{-4}$ & $8.88 \times 10^{-2}$ & $\begin{array}{l}0.284 \\
\left(8.16 \times 10^{-3}\right)\end{array}$ & $1.83 \times 10^{-2}$ & 0 & $-5.13 \times 10^{-2}$ & 0.08 \\
\hline $\begin{array}{l}\text { Freshwater eutrophication } \\
\text { [kgP-eq] }\end{array}$ & $5.75 \times 10^{-3}$ & $8.24 \times 10^{-5}$ & $1.26 \times 10^{-5}$ & $4.96 \times 10^{-3}$ & $\begin{array}{l}2.65 \times 10^{-3} \\
\left(3.59 \times 10^{-4}\right)\end{array}$ & $5.57 \times 10^{-4}$ & 0 & $-2.51 \times 10^{-3}$ & $4.7 \times 10^{-4}$ \\
\hline $\begin{array}{l}\text { Freshwater ecotoxicity } \\
\text { [CTUe] }\end{array}$ & 162 & 3.09 & 1.21 & 118 & $\begin{array}{l}93.8 \\
(6.12)\end{array}$ & 13.7 & 0 & -67.0 & 26.41 \\
\hline $\begin{array}{l}\text { Land use } \\
\text { [kgC-deficit] }\end{array}$ & 157 & 0.653 & 0.670 & 128 & $\begin{array}{l}33.5 \\
(17.3)\end{array}$ & 4.55 & 0 & -9.66 & $N / A$ \\
\hline $\begin{array}{l}\text { Water resource depletion } \\
{[\mathrm{m} 3 \mathrm{H} 2 \mathrm{O}-\mathrm{eq}]}\end{array}$ & 0.817 & $5.81 \times 10^{-5}$ & $1.73 \times 10^{-5}$ & 0.810 & $\begin{array}{l}2.01 \times 10^{-2} \\
\left(-1.66 \times 10^{-3}\right)\end{array}$ & $5.20 \times 10^{-3}$ & 0 & $-1.89 \times 10^{-2}$ & 0.42 \\
\hline
\end{tabular}

contributor with only $0.348 \mathrm{kgCO}_{2}$-eq/ $\mathrm{kg}_{\text {cricket }}$ (approximately $1.6 \%$ of total climate change potential).

The righthand column in Table 6 compares the environmental impact of rearing $1 \mathrm{~kg}$ crickets in the UK for live pet food with $1 \mathrm{~kg}$ crickets in Thailand for human consumption, as assessed in Halloran et al. (2017). The comparison shows that the impact in the current study is larger in every category measured than in the Thailand study.

The results indicate that for all of the impact categories, improvements in feeding and rearing process efficiency have the greatest potential to reduce environmental impact. This is also true of climate change potential, as the second biggest contributing phase (application of frass to land) is directly proportional to the amount of feed wasted within the rearing process.

\subsection{Sensitivity analysis of LCA results}

This LCA study has incorporated many assumptions, and some data are subject to measurement error. In addition, the background processes in SimaPro include uncertainty in the data used. Key data parameters were therefore varied to

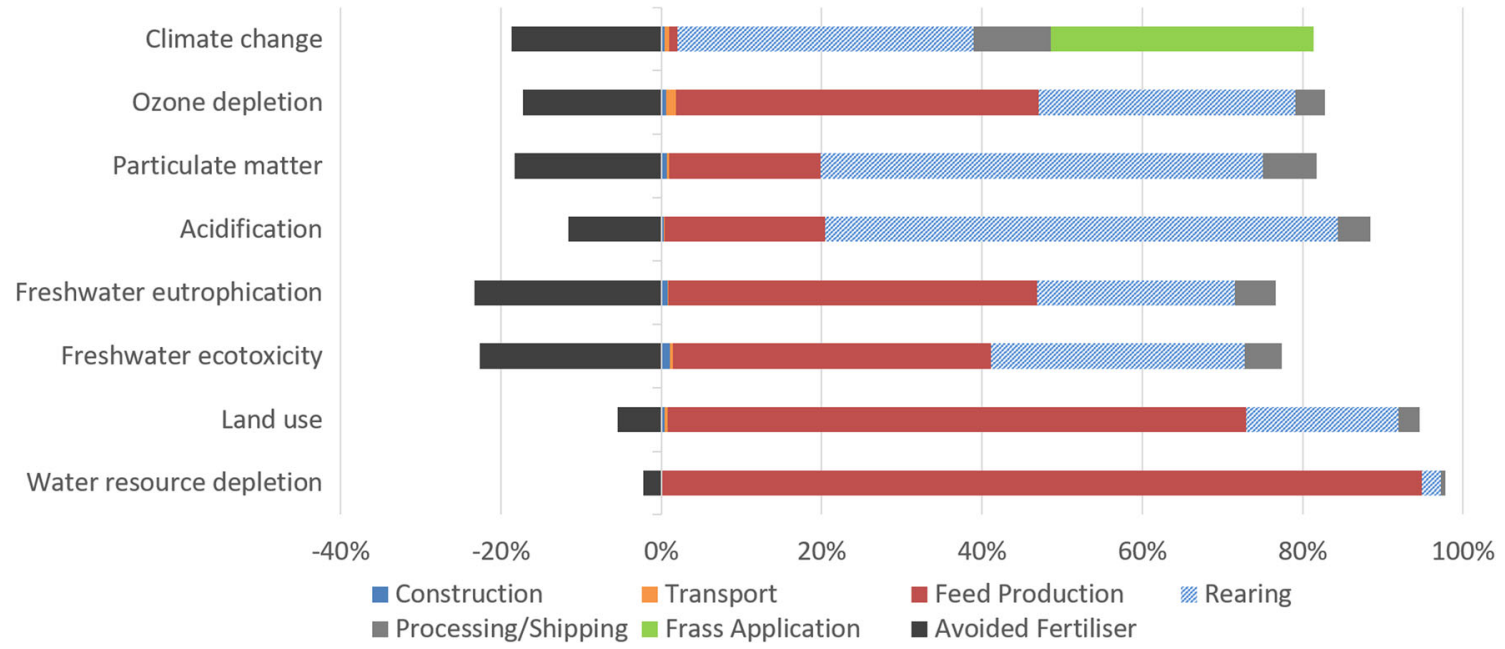

Fig. 2 Relative impact of each life cycle phase out of $100 \%$. Negative values indicate a "benefit" to the environment 
investigate their influence on the results and the sensitivity of the results compared to the background uncertainty.

Sensitivity analysis was carried out on data collected at a site-wide level that were subject to allocation within the LCA and made a substantial contribution to the overall impact: feed, peat, and cardboard. The exact quantity of these going to each of the insect species reared on the farm is not closely monitored and may be subject to error.

Sensitivity analysis also explored the effect of potential variation in the mass of the harvested crickets. They are sold by size and number, but not mass. The conversion to mass was done for this study by measuring a selection of crickets within each size band. The process was not repeated throughout the year. It is possible that there is variability in the harvested weight over time.

Further sensitivity analysis explored the effect of variation in composition between different samples of frass. The collected samples of frass represent only a small fraction of the total mass of frass generated. Therefore, there may be significant variation in its composition between individual rearing boxes, rooms, and days of the year. The variation in composition relates to measured values of dry matter within the frass, and elemental composition (CNPK), as presented in Table 4. Given that the estimated potential to offset fertilizers relies on these measurements, it is important to test the variability this might cause in the results.

In each case, the effect of altering the quantity by \pm $15 \%$, as a uniform distribution across the range, is examined and the results reported in Table 7 as a relative standard deviation from the original impact category value. A test is conducted separately for each of feed input mass, peat input mass, cardboard input mass, and shipping mass. A further sensitivity analysis is conducted varying all four parameters simultaneously. A final sensitivity analysis is conducted on all of the dry matter and CNPK elemental measurement values simultaneously. The results of each sensitivity analysis are compared to the uncertainty inherent in the background processes with no uncertainty from this study applied (the "Bkgr proc." column in Table 7).

The sensitivity analysis shows that, in general, the results appear more dependent on data that are directly linked to the quantity of crickets produced, i.e., feed given to the crickets (feed input mass) and shipping mass, and hence affect other parts of the LCA. These increase the variation in the results when compared to the inherent uncertainty of the background processes. The peat input and cardboard input do not appear to cause much increase over the background uncertainty. Varying all of the parameters together causes the largest variability of the results. Uncertainty in the frass measurement also causes an increase in variability of the results, but not across all of the impact categories (for example freshwater ecotoxicity, or land use). The large relative standard deviation in the water resource depletion is due to the inherent uncertainty of the background process used for the plastic packaging used to export the crickets, with little or no increase from the additional uncertainty in the measured quantities within this study.

\section{Scenarios to explore the influence of business model and how environmental impacts may be reduced}

The LCA results highlight inefficiencies in the rearing process, some of which are due to business operational practices, and others which are due to the live pet food business model. In this section, four scenarios are presented to explore how impacts can be reduced, and to investigate the
Table 7 Sensitivity analysis. Sensitivity tested for a variation of $\pm 15 \%$ of input quantities around nominal value: feed input mass, peat input mass, cardboard input mass, shipping mass, all four varied simultaneously, and frass dry matter and CNPK elemental measurement quantities. Results reported as relative standard deviation. Uncertainty of background processes shown in "Bkgr proc."

\begin{tabular}{|c|c|c|c|c|c|c|c|c|}
\hline \multicolumn{2}{|l|}{ Business as usual impacts } & \multicolumn{7}{|c|}{ Relative standard deviation ( $\%$ to 3 s.f.) } \\
\hline Impact category & $\begin{array}{l}\text { BAU (impact } \\
\text { category units) }\end{array}$ & Bkgr proc. & $\begin{array}{l}\text { Feed input } \\
\text { mass }\end{array}$ & $\begin{array}{l}\text { Peat input } \\
\text { mass }\end{array}$ & $\begin{array}{l}\text { Cardboard } \\
\text { input mass }\end{array}$ & $\begin{array}{l}\text { Shipping } \\
\text { mass }\end{array}$ & All & $\begin{array}{l}\text { Frass } \\
\text { measurement } \\
\text { (DM \& CNPK) }\end{array}$ \\
\hline Climate change $\left[\mathrm{kgCO}_{2}\right.$-eq] & 21.1 & 2.53 & 3.27 & 2.51 & 2.53 & 5.23 & 5.70 & 5.61 \\
\hline Ozone depletion [kgCOFC-11-eq] & $1.79 \times 10^{-6}$ & 2.32 & 4.28 & 2.14 & 2.20 & 5.67 & 6.82 & 2.59 \\
\hline $\begin{array}{l}\text { Particulate matter } \\
\text { [kgPM2.5-eq] }\end{array}$ & $2.04 \times 10^{-2}$ & 1.69 & 2.86 & 1.69 & 1.66 & 4.71 & 5.28 & 2.38 \\
\hline Acidification [molcH+eq] & 0.342 & 0.78 & 7.13 & 0.77 & 0.78 & 7.99 & 10.8 & 1.19 \\
\hline Freshwater eutrophication [kgP-eq] & $5.75 \times 10^{-3}$ & 8.78 & 8.99 & 8.51 & 8.58 & 9.96 & 11.2 & 9.27 \\
\hline Freshwater ecotoxicity [CTUe] & 162 & 4.96 & 5.95 & 4.82 & 3.96 & 7.60 & 7.02 & 4.72 \\
\hline Land use [kgC-deficit] & 157 & 2.86 & 7.07 & 2.85 & 2.87 & 7.85 & 10.2 & 2.85 \\
\hline Water resource depletion $\left[\mathrm{m}^{3} \mathrm{H}_{2} \mathrm{O}-\mathrm{eq}\right]$ & 0.817 & 48.3 & 49.4 & 49.5 & 47.4 & 49.9 & 50.1 & 48.5 \\
\hline
\end{tabular}


implications of moving to a hybrid live pet food/human food business model. The scenarios explored here regard changes to the current case study farm practices, and are not intended for comparison to Halloran et al. (2017). Results for each scenario are compared to the existing business practices, termed here Business As Usual (BAU). To enable the implications of a move to a hybrid business model that combines production of live pet food with food for human consumption to be better understood, only the life cycle phases which are common to the rearing processes for both live pet food and human food are considered. Therefore, the processing for export phase is omitted, not least because the case study farm had not, at the time of the study, finalized the processing for human food techniques, and hence, assessment of this stage was not possible. A full set of BAU data for the life cycle without the processing for export stage is shown for reference in Table S8. Full data for each of the scenarios is available in Tables S9 to S12. The scenarios are as follows:

A. Frass exploitation through anaerobic digestion processing, and use of the resulting methane $\left(\mathrm{CH}_{4}\right)$ in a combined heat and power (CHP) engine.

B. The feed conversion ratio is optimized and overproduction eliminated.

C. The crickets are all harvested at their full weight at the end of the growth cycle.

D. Combination of scenarios B and C.

\subsection{Scenario A: frass exploitation}

Scenario A explores exploitation of waste streams. As explained in Section 3.5, it was assumed that the frass application to land could offset other mineral NPK fertilizers, leading to a reduction in climate change potential of $-6.27 \mathrm{kgCO}_{2}$-eq $/ \mathrm{kg}_{\text {cricket }}$. However, the case study business is interested in exploring alternative uses for the frass, such as processing in an anaerobic digestion (AD) plant prior to application to land. It has been shown that byproducts of insect rearing can be used to generate biogas (Bulak et al. 2020) with $\mathrm{CH}_{4}$ yields of 208 to $259 \mathrm{ml} / \mathrm{g}$ volatile solids (VS), which compares favorably with other AD feedstocks (e.g., $245 \mathrm{ml} / \mathrm{g}$ VS for wheat (Amon et al. 2007)). The $\mathrm{CH}_{4}$ could be used within a combined heat and power (CHP) engine on the farm site and the digestate, which is rich in NPK, can still be spread to land to displace mineral fertilizers (Nicholson et al. 2016). It can be assumed that all of the carbon is still emitted as $\mathrm{CO}_{2}$, but that for every $1 \mathrm{~m}^{3}$ of $\mathrm{CH}_{4}$ produced by the $\mathrm{AD}$ process, $10.97 \mathrm{kWh}$ of energy is made available to offset other sources (BEIS 2017). The details of the calculation of total energy recovered from the frass are given in the Supplementary Information, Section 3.1.

\subsection{Scenario B: feed conversion ratio optimization and overproduction elimination}

Scenario B explores the effect that optimizing the feed conversion ratio (FCR - see Section 3.1) and elimination of overproduction may have upon environmental impact. The source of overproduction as a result of the need to provide a reliable supply of live crickets for the pet food market was discussed in Section 3.9. Such an overproduction could be avoided if producing crickets for human consumption as any excess crickets can be processed into a shelf stable final product (for example cricket flour), which can be stored for longer periods of time than the living crickets of the live pet food business model. The overproduction is not measured by the business, but is reflected in the rather high FCR discovered within this study. Much of the rest of the high FCR comes from rearing practices which cause potential overfeeding: the crickets are reared in cardboard boxes in which cardboard egg trays are stacked vertically and packed closely together, making it hard to see into the bottom of the boxes. Feed is added to the top of the box, but can readily percolate down to the bottom, where it can no longer be seen by staff. Without carefully monitoring the quantity of feed already given, there is no way to ensure that overfeeding does not occur.

This scenario thus assumes that addressing the two issues allows a reduction of FCR to $1.47: 1$ (Lundy and Parrella 2015). This results in feed input reduction from $113.28 \mathrm{t} / \mathrm{year}$ to $18.32 \mathrm{t} /$ year (a reduction of $83.8 \%$ ) to produce $12.46 \mathrm{t} /$ year crickets. Due to the reduced feed input, frass production is reduced and is accounted for within this scenario. There is no other change in consumables as the crickets are still reared in the same number of carboard boxes. The 1.47:1 FCR is also used in Halloran et al. (2017) when exploring a future cricket farm scenario.

\subsection{Scenario C: harvesting at full weight}

Scenario C tests the effect of harvesting the crickets at full weight, as opposed to a variety of sizes. All other aspects of the business model are kept constant. As the live pet food model requires crickets of various sizes to be harvested, the average mass of the individual crickets shipped out of the farm is approximately $42 \mathrm{mg}$ for G. sigillatus and $320 \mathrm{mg}$ for G. bimaculatus. This is well below what might be considered their respective optimal harvesting weights of $108 \mathrm{mg}$ and $616 \mathrm{mg}$ (as specified by the business). By harvesting only at the optimal mass, the net output from the farm may be expected to increase from the current $12.46 \mathrm{t} /$ year to $25.61 \mathrm{t} /$ year, an increase of $105.5 \%$ with potentially little change in other resource demands. It 
should be noted that harvesting at a larger weight, with no associated increase in feed consumption, is equivalent to reducing the FCR from 9.09:1 to approximately 5.13:1. However, this is still far above a potential optimal of 1.47:1 (Lundy and Parrella 2015). Furthermore, this scenario does not address the issue of overproduction, which is addressed in scenario B. Because the crickets are harvested at full weight, the consumables used per kilogram of crickets produced reduces. Therefore, reductions are assumed in the quantity of carboard, peat, and water per kilogram of crickets.

\subsection{Scenario D: combination of scenarios B and C}

Scenario D explores the combination of scenarios B and C, by looking at the combined effect of harvesting at full weight and a drive to maximize rearing efficiencies. This is what might be expected from a shift to rearing crickets for the human food market. If the more efficient feeding regime were combined with harvesting at full weight, the annual production of crickets would become $25.61 \mathrm{t}$ /year (as in scenario C), and the required feed would reduce from 113.28 $\mathrm{t}$ /year (BAU) to $37.64 \mathrm{t} / \mathrm{y}$ ear. This new feed requirement is derived from the harvest mass and target FCR (1.47:1). It represents a $66.8 \%$ reduction in mass from the current feed demand of $113.28 \mathrm{t} /$ year, with the same improvement in output as calculated for scenario C (105.5\%).

\subsection{Scenario analysis results}

The results and sensitivity are presented as a fractional change of environmental impact when compared to BAU for each impact category (Fig. 3). For reference, a fractional change of 0.5 indicates that the scenario has half the environmental impact of the BAU within that impact category. Full numerical results for each of the impact categories and life cycle phases are given in Supplementary Information, Section 3.2, Tables S9 to S12.

When considering all impact categories together, and assuming equal weighting, the biggest reduction comes, as expected, from scenario D (54\%: this value is the average of the fractional change of all impact categories shown in Fig. 3). This is due to the largest reduction in feed and consumables per kilogram of crickets produced. This is followed by scenario B (47\%). From this, we deduce that the greatest reduction in environmental impact comes from reducing the feed used to rear $1 \mathrm{~kg}$ of crickets, and to a lesser extent, the quantity of peat and carboard. The smallest reduction is scenario A (18\%), demonstrating that making use of waste products is not as beneficial as reducing the production of those waste products in the first place.

The reductions within scenarios $\mathrm{C}$ and $\mathrm{D}$ come in particular from a large reduction in acidification potential (AP) within the rearing phase, and from similar large reductions in water resource depletion (WRD) and land use change (LU) from the feed production phase. In particular, the WRD from feed production reduces from $0.810 \mathrm{~m}^{3}$ water-eq in BAU to $0.131 \mathrm{~m}^{3}$ water-eq in scenarios B and D.

By contrast, the greatest reductions due to scenario A come from a reduction in climate change $(\mathrm{CC})$ in frass application (due to the removal of carbon from the frass via the anaerobic digestion process) and the use of the biogas to displace woody biomass in the heat process, and thereby

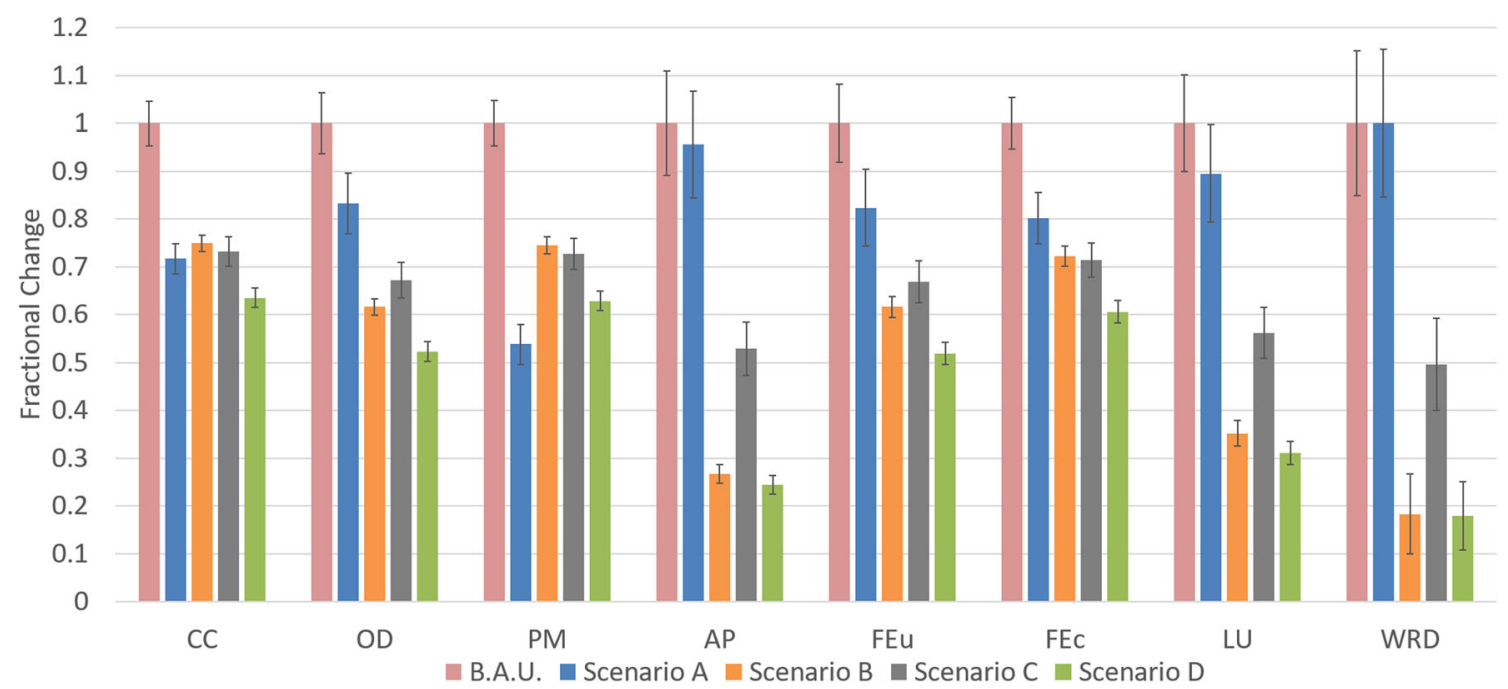

Fig. 3 Fractional change in impact for producing $1 \mathrm{~kg}$ of crickets compared to BAU as a function of impact category: CC, climate potential; FEu, freshwater eutrophication; FEc, freshwater ecotoxicity; LU, land use change; WRD, water resource depletion. Sensitivity ( \pm change; OD, ozone depletion; PM, particulate matter; AP, acidification

$15 \%$ as per Section 4.1 ) is shown as an error bar 
also reducing particulate matter (PM) impact. Otherwise, in all other impact categories, scenarios B, C, and D outperform scenario A.

\section{Discussion}

In this section, we discuss changes in rearing practices that may reduce the environmental impacts of the current production process, the implications of the heating requirements due to the climate in the UK, the potential benefits of moving to a hybrid business model, and the limitations of this study.

\subsection{Options for reducing materials consumption}

Inefficient feeding practices that result in a high feed conversion ratio have been shown to be one of the biggest contributors to environmental impact. Optimizing the rearing process to reduce the quantity of feed passing through the system is a priority both in terms of environmental impact, but also in terms of cost reduction. However, achieving this reduction will require changes to the rearing process: in particular, the cardboard rearing boxes need replacing. The crickets are kept in cardboard boxes which are discarded at the end of the rearing cycle to reduce the potential for disease spreading. Replacing the cardboard boxes with something transparent would allow the quantity of feed which percolates to the bottom of the box to be seen more easily and overfeeding might therefore be reduced. This also yields an additional benefit: picking a material which is reusable will reduce costs and environmental impact from continually replacing the cardboard. However, that change must be made in context of the certainty with which the boxes may be sufficiently cleaned in order to eliminate the potential for disease to be spread during reuse. Furthermore, care must be taken in order to ensure that an effective cleaning process does not result in burden shifting of impacts due to use of harsh cleaning chemicals.

\subsection{Heating requirements and geographical location}

Neither types of cricket species that are the subject of this study (G. bimaculatus nor G. sigillatus) are native to the UK: they are commonly found in the tropics and sub-tropics (Eades et al. 2018; Roskov et al. 2018). The farm has found that they thrive best at a temperature of approximately $30^{\circ} \mathrm{C}$. The UK has a temperate climate, with an average annual temperature ranging between $16.3{ }^{\circ} \mathrm{C}$ in July down to $3.4{ }^{\circ} \mathrm{C}$ in January (CCKP 2018). As such, the crickets require nearconstant heating in order to grow effectively. The LCA shows that heating accounts for $3.71 \mathrm{kgCO}_{2}$-eq $/ \mathrm{kg}_{\text {cricket }}$ of the rearing phase climate change potential of $12.4 \mathrm{kgCO}_{2}$-eq $/ \mathrm{kg}_{\text {cricket }}$, and $1.01 \times 10^{-2} \mathrm{kgPM} 2.5-\mathrm{eq} / \mathrm{kg}_{\text {cricket }}$ of the total particulate matter of $2.04 \times 10^{-2} \mathrm{kgPM} 2.5-\mathrm{eq} / \mathrm{kg}_{\text {cricket }}$ (see Table 6). This compares to the total climate change potential of $2.57 \mathrm{kgCO}_{2}-\mathrm{eq} / \mathrm{kg}_{\text {cricket }}$ and particulate matter of $5.0 \times$ $10^{-3} \mathrm{kgPM} 2.5-\mathrm{eq} / \mathrm{kg}_{\text {cricket }}$ for rearing crickets in Thailand (Halloran et al. 2017). Utilizing heat recovery from the exhaust flue has the potential to make a significant reduction in environmental impact of the heating required for rearing crickets in the UK. However, rearing in Thailand and the UK is very different, with, for example, crickets being reared in open pens in Thailand. Therefore, further studies are required to explore whether the environmental impacts of rearing crickets in the UK for the human food market could be comparable to importing produce from countries such as Thailand.

\subsection{Benefits of a hybrid live pet food/human food business model}

The results of this study have highlighted that the rearing of crickets for live pet food cannot be considered as indicative of the potential environmental impacts of rearing crickets for human food in the UK, as the use for which the crickets are being reared affects the environmental impact of the rearing process. On first impression, it may appear that the products are the same, and that the rearing process is independent of the use phase (consumption by pets or humans), and therefore, the reason for which the crickets are reared should not matter. However, the rearing of crickets for live pet food as opposed to human food results in different products. It should be considered that the product of the rearing process is not defined by the individual cricket species, but it is defined by the combination of cricket species and their size at harvesting.

Overproduction is an essential aspect of producing crickets for the live pet food market, and adopting a hybrid live pet food/human food business model may be an effective way of making use of surplus crickets. The overproduction comes from two main sources: the need to meet fluctuating customer demand and the need to protect against cricket population crash due to disease sweeping through the rearing facility. The long rearing cycle of crickets and the short-term nature of customer orders means overproduction is required in order to comfortably accommodate both these eventualities. It may be possible to mitigate disease losses through the use of antimicrobials, but it is not clear whether this would be effective, or desirable in a world already concerned about over-use of antimicrobials (Xiong et al. 2018). Instead, adopting a hybrid business model is a way to use the surplus crickets to produce a more shelf stable product (for example cricket powder) and thus effectively eliminate the live pet food overproduction issues. The net environmental impact should only be assessed once a business model shift has been made. 


\subsection{Limitations of this study}

Many of the limitations of the study discussed relate to the uncertainty of quantifying the resources which are allocated to the crickets. These included the quantities of feed, peat, consumables, and utilities (electricity, heat, and water allocation) required to rear a given mass of crickets. In particular, waste water treatment is not accounted for as its fate was not known. Limitations also include uncertainty in the mass of crickets and frass produced, the CNPK content of the frass and the amount of overproduction. All of these issues are being addressed by the farm, which is introducing a dedicated rearing room for the purpose of improving the efficiency of the feeding process, and to weigh the net inputs and outputs. This will improve the accuracy of future LCA studies.

Further limitations regarding potential use of frass are not taken into account here. Aside from the carbon and NPK nutrient content, it also contains chitin, which has been shown to alter the balance of microbiota in soil and boost plant growth (Sharp 2013). This indicates that the frass acts to improve the soil and support plant growth to an extent greater than that assumed from the simple replacement of NPK fertilizers with the equivalent quantity within the frass. A study would need to be undertaken to understand the true potential benefits that the frass could offer as a soil supplement.

An original aim of the study was to compare the impacts of rearing crickets for human food to other sources of nutrition. However, the discussed inefficiencies within the rearing system were greater than anticipated at the outset by either the researchers or case study company. Therefore, it is not possible to make such comparisons within this study. Rather, this study indicates what changes should be made to reduce the impact of the rearing, and acts as a learning experience for the transition to incorporate rearing for human food within the business model.

One final limitation of note regards the potential to compare the results of this study to those of Halloran et al. (2017) - the only other published LCA study of cricket rearing. Our study assesses G. bimaculatus and G. sigillatus whereas Halloran et al's study assesses G. bimaculatus and A. domesticus. Our study assumes that the differences in the environmental impacts of rearing G. bimaculatus, G. sigillatus, and A. domesticus are negligible. This assumption is necessary because Halloran et al's results are aggregated for the two species of crickets.

\section{Conclusion}

A life cycle assessment has been presented for rearing crickets for the live pet food market in the UK. The LCA accounted for all cradle-to-farm-gate inputs and outputs associated with rearing the crickets and preparation for shipping to retail. The environmental impact was found to be larger across all impact categories than the only known comparable study, which is for rearing crickets in Thailand for human consumption (Halloran et al. 2017).

The current study has highlighted inefficiencies in the case study farm's rearing practices, indicating that the biggest reductions in environmental impact may be through reducing throughput of feed, materials, and heating in the rearing process. Such reductions would result in significant improvements across all impact categories reported. At the time of writing, measures are being implemented by the business to mitigate these issues, as they are a financial issue, as well as an environmental burden. A future study will be conducted to explore the benefits.

This study and Halloran et al. (2017) do not compare like-tolike, and this paper highlights how the live pet food business model differs from the human food business model. For example, when supplying the live pet food market, overproduction is necessary to provide customers with a reliable source of live crickets, and these must be of varying weights to meet the requirements of different types of pets. Such differences contribute environmental burdens that would not be incurred when producing crickets for human food. Therefore, this study demonstrates that the product of each rearing process is not a function of the cricket species alone, which may lead to an assumption that what the crickets are reared for is irrelevant to the environmental impact of rearing process. Rather, the product is a factor of both the cricket species and its size. Hence, the rearing of crickets for live pet food is in effect a production system with multiple co-products and the environmental impact of it cannot be considered indicative of the production process for human food, which has just one product.

The UK already has a thriving live pet food market, which by its very nature must be geographically localized. Live pet food producers are actively exploring new business opportunities in rearing crickets for the human food market, while continuing to supply the live pet food market. This study points to the benefits that might be achieved through a hybrid live pet food and human food business model. Such a hybrid business model in effect adds a further co-product to the production process, one which is able to absorb the overproduction created by a live pet food business operating in isolation. Thus, the environmental burden of live pet food production can be reduced, and at the same time, the market needs for cricket-based food for humans met.

Funding information This work was undertaken as part of the Stepping Up project (grant number EP/N00583X/1) which is funded by the UK Engineering and Physical Research Science Council (EPSRC). In addition, financial support was received from the UK Knowledge Transfer Partnerships programme (KTP). KTP aims to help businesses to improve their competitiveness and productivity through the better use of knowledge, technology, and skills that reside within the UK knowledge base. This successful Knowledge Transfer Partnership project, funded by UK 
Research and Innovation through Innovate UK, is part of the UK Government's Industrial Strategy.

\section{Compliance with ethical standards}

Conflict of interest The authors declare that they have no conflict of interest.

Open Access This article is licensed under a Creative Commons Attribution 4.0 International License, which permits use, sharing, adaptation, distribution and reproduction in any medium or format, as long as you give appropriate credit to the original author(s) and the source, provide a link to the Creative Commons licence, and indicate if changes were made. The images or other third party material in this article are included in the article's Creative Commons licence, unless indicated otherwise in a credit line to the material. If material is not included in the article's Creative Commons licence and your intended use is not permitted by statutory regulation or exceeds the permitted use, you will need to obtain permission directly from the copyright holder. To view a copy of this licence, visit http://creativecommons.org/licenses/by/4.0/.

\section{References}

Alexander P, Brown C, Arneth A, Dias C, Finnigan J, Moran D, Rounsevell MDA (2017) Could consumption of insects, cultured meat or imitation meat reduce global agricultural land use? Glob Food Secur 15:22-32. https://doi.org/10.1016/j.gfs.2017.04.001

Allegretti G, Talamini E, Schmidt V, Bogorni PC, Ortega E (2018) Insect as feed: an emergy assessment of insect meal as a sustainable protein source for the Brazilian poultry industry. J Clean Prod 171:403-412. https://doi.org/10.1016/j.jclepro.2017.09.244

Amon T et al (2007) Methane production through anaerobic digestion of various energy crops grown in sustainable crop rotations. Bioresour Technol 98:3204-3212. https://doi.org/10.1016/j.biortech.2006.07. 007

Bava L, Jucker C, Gislon G, Lupi D, Savoldelli S, Zucali M, Colombini S (2019) Rearing of Hermetia illucens on different organic by-products: influence on growth, waste reduction, and environmental impact. Animals 9(6):289. https://doi.org/10.3390/ani9060289

BEIS (2016) UK government GHG conversion factors for company reporting 2016. Department for Business, Energy \& Industrial Strategy, London

BEIS (2017) Estimated average calorific values of fuels (DUKES A.1A.3). Department for Business, Energy \& Industrial Strategy, London

BEIS (2018a) Fuel used in electricity generation and electricity supplied: Energy Trends 5.1. Department for Business, Energy \& Industrial Strategy, London

BEIS (2018b) Sub-National Electricity Consumption Statistics 2005 2016. Department for Business, Energy \& Industrial Strategy, London

Boldrin A, Andersen JK, Møller J, Christensen TH, Favoino E (2009) Composting and compost utilization: accounting of greenhouse gases and global warming contributions. Waste Manag Res 27:800 812. https://doi.org/10.1177/0734242x09345275

Bulak P, Proc K, Pawłowska M, Kasprzycka A, Berus W, Bieganowski A (2020) Biogas generation from insects breeding post production wastes. J Clean Prod 244:118777. https://doi.org/10.1016/j.jclepro. 2019.118777

CCKP (2018) Climate change knowledge portal. The World Bank. http:// sdwebx.worldbank.org/climateportal/. Accessed 6th August 2018
DEFRA (2014) Inventory of ammonia emissions from UK Agriculture 2013. Department for Environment, Food and Rural Affairs, London

Eades D, Otte D, Cigliano M, Braun H (2018) SF Orthoptera: Othoptera Spercies File (version 5.0, Dec 2017), 31/07/2018 edn. Species 2000: Naturalis, Leiden, the Netherlands

le Féon S, Thévenot A, Maillard F, Macombe C, Forteau L, Aubin J (2019) Life cycle assessment of fish fed with insect meal: case study of mealworm inclusion in trout feed in France. Aquaculture 500:8291. https://doi.org/10.1016/j.aquaculture.2018.06.051

Foley JA et al (2011) Solutions for a cultivated planet. Nature 478:337342. https://doi.org/10.1038/nature10452

Gerber PJ et al (2013) Tackling climate change through livestock-a global assessment of emissions and mitigation opportunities. Food and Agriculture Organization of the United Nations, Rome

Halloran A, Hanboonsong Y, Roos N, Bruun S (2017) Life cycle assessment of cricket farming in north-eastern Thailand. J Clean Prod 156: 83-94. https://doi.org/10.1016/j.jclepro.2017.04.017

Lundy ME, Parrella MP (2015) Crickets Are Not a Free Lunch: Protein Capture from Scalable Organic Side-Streams via High-Density Populations of Acheta domesticus. PLoS ONE 10:e0118785. https://doi.org/10.1371/journal.pone.0118785

Miglietta P, De Leo F, Ruberti M, Massari S (2015) Mealworms for food: a water footprint perspective. Water 7:6190

Mudie S, Essah EA, Grandison A, Felgate R (2016) Electricity use in the commercial kitchen International. J Low-Carbon Technol 11:66-74. https://doi.org/10.1093/ijlct/ctt068

Nicholson F et al. (2016) Work Package 2 Final Report (2010-2015), Field experiments for quality digestate and compost in agriculture. Waste \& Resources Action Programme. http://www.wrap.org.uk/ content/digestate-and-compost-agriculture-dc-agri-reports. Accessed 21 Jun 2020

NREL (2018) PVWatts calculator. National Renewable Energy Laboratory. https://pvwatts.nrel.gov/pvwatts.php. Accessed 30th July 2018

Oldfield TL, Sikirica N, Mondini C, López G, Kuikman PJ, Holden NM (2018) Biochar, compost and biochar-compost blend as options to recover nutrients and sequester carbon. J Environ Manag 218:465476. https://doi.org/10.1016/j.jenvman.2018.04.061

Oonincx D, de Boer IJM (2012) Environmental Impact of the Production of Mealworms as a Protein Source for Humans - A Life Cycle Assessment. PLoS One 7:5. https://doi.org/10.1371/journal.pone. 0051145

Roffeis M et al (2015) Pig manure treatment with housefly (Musca domestica) rearing - an environmental life cycle assessment. J Insects Food Feed 1:195-214. https://doi.org/10.3920/jiff2014.0021

Roffeis M, Almeida J, Wakefield M, Valada T, Devic E, Koné NG, Kenis M, Nacambo S, Fitches E, Koko G, Mathijs E, Achten W, Muys B (2017) Life Cycle Inventory Analysis of Prospective Insect Based Feed Production in West Africa. Sustainability 9:27. https://doi.org/ $10.3390 /$ su9101697

Roskov Y et al. (2018) Species 2000 \& ITIS Catalogue of Life, 2018 Annual Checklist. Species 2000: Naturalis, Leiden, the Netherlands. www.catalogueoflife.org/annual-checklist/2018. Accessed 6/8/2018 2018

Salomone R, Saija G, Mondello G, Giannetto A, Fasulo S, Savastano D (2017) Environmental impact of food waste bioconversion by insects: application of life cycle assessment to process using Hermetia illucens. J Clean Prod 140(Part 2):890-905. https://doi.org/10.1016/ j.jclepro.2016.06.154

Sharp R (2013) A review of the applications of chitin and its derivatives in agriculture to modify plant-microbial interactions and improve crop yields. Agronomy 3:757

Smetana S, Mathys A, Knoch A, Heinz V (2015) Meat alternatives: life cycle assessment of most known meat substitutes. Int J Life Cycle Assess 20:1254-1267. https://doi.org/10.1007/s11367-015-0931-6 
Smetana S, Palanisamy M, Mathys A, Heinz V (2016) Sustainability of insect use for feed and food: Life cycle assessment perspective. J Clean Prod 137:741-751. https://doi.org/10.1016/j.jclepro.2016.07. 148

Smetana S, Schmitt E, Mathys A (2019a) Sustainable use of Hermetia illucens insect biomass for feed and food: attributional and consequential life cycle assessment. Resour Conserv Recycl 144:285296. https://doi.org/10.1016/j.resconrec.2019.01.042

Smetana S, Schmitt E, Mathys A (2019b) Sustainable use of Hermetia illucens insect biomass for feed and food: attributional and consequential life cycle assessment. Resour Conserv Recycl 144:285296. https://doi.org/10.1016/j.resconrec.2019.01.042

Tedesco DE, Conti C, Lovarelli D, Biazzi E, Bacenetti J (2019) Bioconversion of fruit and vegetable waste into earthworms as a new protein source: the environmental impact of earthworm meal production. Sci Total Environ 683:690-698. https://doi.org/10. 1016/j.scitotenv.2019.05.226

Thevenot A et al (2018) Mealworm meal for animal feed: environmental assessment and sensitivity analysis to guide future prospects. J Clean Prod 170:1260-1267. https://doi.org/10.1016/j.jclepro.2017.09.054

van Huis A, Itterbeeck J, Klunder H, Mertens E, Halloran A, Muir G, Vantomme P (2013) Edible insects: future prospects for food and feed security. Food and Agriculture Organisation of the United Nations, Rome

van Huis A, Oonincx D (2017) The environmental sustainability of insects as food and feed. A review. Agron Sustain Dev 37:14. https:// doi.org/10.1007/s13593-017-0452-8

van Zanten HHE, Mollenhorst H, Oonincx D, Bikker P, Meerburg BG, de Boer IJM (2015) From environmental nuisance to environmental opportunity: housefly larvae convert waste to livestock feed. J Clean Prod 102:362-369. https://doi.org/10.1016/j.jclepro.2015. 04.106

Walsh CL et al (2016) Adaptation of water resource systems to an uncertain future. Hydrol Earth Syst Sci 20:1869-1884. https://doi.org/10. 5194/hess-20-1869-2016

Webb J, Misselbrook TH (2004) A mass-flow model of ammonia emissions from UK livestock production. Atmos Environ 38:2163-2176. https://doi.org/10.1016/j.atmosenv.2004.01.023

Xiong WG, Sun YX, Zeng ZL (2018) Antimicrobial use and antimicrobial resistance in food animals. Environ Sci Pollut Res 25:1837718384. https://doi.org/10.1007/s11356-018-1852-2

Publisher's note Springer Nature remains neutral with regard to jurisdictional claims in published maps and institutional affiliations. 